\title{
DÜBLIN
}

Technological University Dublin

ARROW@TU Dublin

\section{Arts Festivals, Urban Tourism and Cultural Policy}

Bernadette Quinn

Technological University Dublin, bernadette.quinn@tudublin.ie

Follow this and additional works at: https://arrow.tudublin.ie/tfschhmtbook

Part of the Human Geography Commons, and the Urban Studies and Planning Commons

\section{Recommended Citation}

Quinn, B. (2013) Arts festivals, tourism, cities, urban policy. In Stevenson, D. and Matthews, A. (Eds) (2013) Culture and the City: Creativity, Tourism, Leisure, pp. 69-84. Oxon: Routledge

This Book Chapter is brought to you for free and open access by the School of Tourism \& Hospitality Management at ARROW@TU Dublin. It has been accepted for inclusion in Books / Book chapters by an authorized administrator of ARROW@TU Dublin. For more information, please contact arrow.admin@tudublin.ie, aisling.coyne@tudublin.ie, gerard.connolly@tudublin.ie. Funder: None 


\section{Arts Festivals, Urban Tourism and Cultural Policy}

Dr. Bernadette Quinn

Department of Tourism

Dublin Institute of Technology

Cathal Brugha St.

Dublin 1.

Tel: $00353(0) 14027557$

Bernadette.Quinn@dit.ie

\section{Brief biography}

Bernadette Quinn is a geographer working in the Tourism Department at the Dublin Institute of Technology. Her research interests include festivals, tourism and cultural change, and tourism and social justice. Her work has been published in a variety of journals including the Annals of Tourism Research, Gender, Place and Culture and Urban Studies. 


\begin{abstract}
Arts festivals are in the ascendant. Framed within an array of neo-liberal, culture-led urban regeneration strategies, they are now a mainstay of urban tourism and urban policy-making. As such, they face growing competitive pressures and competing agendas, and the need for a set of coherent goals and policy frameworks is vital. While a review of the literature clearly shows that arts festivals can deliver a series of benefits that separately meet the cultural policy and urban tourism policy objectives, there is little to suggest that cities normatively engage in comprehensive, integrated policy-making for urban arts festivals. This paper critically reviews a range of literature that investigates how arts festivals further cultural policy and tourism policy objectives in urban contexts, with a particular focus on recent developments in Ireland. Overall, it argues that current conceptualisations of arts festivals within urban policy frameworks are imbalanced. While the proliferation of arts festivals signals expansion for the sector, the ready transferability of arts festivals into tourist attractions and city image-makers raises the prospect of a new dichotomy within a city's supply of artistic offerings, with the visible and instantly appealing, e.g. festivals, being more likely to prosper through a variety of public funding, publicprivate ventures and private sponsorship arrangements, than other cultural organisations with less potential for spectacle. It concludes by arguing that common bases for collaboration need to be identified between the arts festivals and tourism sectors, and that these common bases need to be conceptualised within the broader cultural and urban policy arenas in which arts festival are now firmly implicated.
\end{abstract}

Keywords: arts festivals; urban tourism; cultural policy; collaboration; Ireland 


\section{Arts Festivals, Urban Tourism and Cultural Policy}

\section{Introduction}

Until recent decades, arts festivals were of little interest to any policy-makers except those specifically charged with culture. Even then, arts festivals were something of a 'poor relation' of cultural activities, often viewed in policy terms as a first step towards the development of more sustainable, year-round, 'productive' cultural activities. This is no longer the case. Arts festivals have been in the ascendant since the late 1980s. Framed within a broader array of neo-liberal, culture-led urban regeneration strategies, arts festivals are now a mainstay of urban tourism and urban policy-making (Nurse 2004, Gotham 2005). As Miles and Paddison (2005:834) note, 'the rapidity with which culture has ascended the urban policy agenda has been little short of extraordinary'. Various commentators have pointed out that the use of culture to advance a range of social and economic goals is most apparent in cities (Griffiths et al. 2003, Griffiths 2006) and urban arts festivals have proliferated to a greater degree than any other type (Pejovic 2009). In the last 20 years, countless arts festivals have been staged in the interest of invigorating urban economies, regenerating entire cities or city districts, and introducing or repositioning cities on the ever-more competitive global stage (Shin 2004, Yardimci 2007).

This repositioning of arts festivals has heightened a series of tensions between the policy domains that arts festivals increasingly straddle (Waterman 1998). These tensions are played out every day in festival settings as organisations strive to achieve their artistic objectives while remaining competitive, maintaining the support of key stakeholders and attracting sufficient numbers of local and visiting audiences, producers, artists, directors, critics and the all important media attention. Competing agendas have to be managed, and the tourism sector in particular is very forthright in its instrumental approach to culture and to arts festivals. MacCannell's (1992:1) assertion that 'tourism is not just an aggregate of merely commercial activities, it is also an ideological framing of history, nature and tradition, a framing that has the power to reshape culture and nature to its own needs', is a real issue for the arts festival sector. Amidst such competitive pressures and competing agendas, the need for a set of coherent goals and policy frameworks is vital. 
Yet, there is little in the literature to suggest that cities normatively engage in such processes. While there are undoubtedly some exceptions where the policy ambitions of individual arts festivals are closely interwoven into the broader policy frameworks operating in a city at large, in general, there is an urgent need to create new policy frameworks to chart an equitable path for the future development of urban arts festivals. To date, there has been little debate about such a need in the academic literature, although importantly, in a recent paper in this journal, Getz (2009: 62) has called for the development of a comprehensive policy for planned events, arguing that 'public policy pertaining to festivals and other planned events is generally fractionalized .. not comprehensive .. and fails to integrate events effectively with all the relevant policy domains. Maughan (2009: 57) too, has written of the 'relatively weak links between festivals and non-cultural policy agendas, and tensions which hinder the development of the sector' and argued that festivals do not appear to be party to the existing dialogue between tourism and business. Arguments of this nature are difficult to refute. Recent decades have seen an unashamedly instrumental approach to both the use of culture to further neo-liberal urban agendas, and the use of arts festivals in urban planning, with a clear privileging of some interests above others. This paper calls for critical reflection on the outcomes of this approach to date and tries to tease out some of the complexities at issue in moving towards more joined-up policy thinking about arts festivals. It reviews recent developments in the literature in the search for answers to such questions as: how well do arts festivals serve the interests of urban destinations? And how are arts festivals faring out in the context of prevailing urban policy agendas?

The paper draws on recent contributions to the diverse and growing literatures on arts festivals that emanate from a range of disciplinary perspectives including urban studies, political economy, geography, theatre studies and event studies. It uses a number of international examples drawn from these literatures to make its arguments, while also relying strongly on the author's knowledge of Irish festival contexts. The paper begins by tracing the changing roles of arts festivals in recent times, arguing that as their policy relevance broadens, their historical positioning within the cultural policy domain is becoming increasingly complicated. In order to investigate the complexities at issue, the paper briefly examines the various ways in which festivals have furthered cultural policy agendas in the past. Arts festivals' close links with 
urban tourism and by extension, with urban policy agendas more widely, are then examined and problematised. Finally, a series of conclusions are drawn.

\section{Changing role of arts festivals}

The rhythm of human civilisations has always been punctuated by moments when collectively, people at local, national and international levels celebrate the arts. The word 'festival' derives from the latin 'festum' meaning feast (Isar 1976) and festivals are known to have existed for a very long time. While the arts have long been pivotal to how people celebrate collectively, commentators like Allen and Shaw (2000) and Brennetot (2004) have pointed to the proliferation of arts festivals since the middle of the $20^{\text {th }}$ century. Since then, and especially since the late 1980 s, countries across the developed world have seen arts festivals proliferate and become transformed into an industry of very sizeable proportions. By now, numerous commentators have pointed to the prevalence of arts festivals in contemporary society. According to Rolfe (1992), more than half of the arts festivals existing in the UK date to the 1980s, while Allen and Shaw (2000) estimate that the UK festival population in total exceeds 550. Brennetot (2004) reports a spectacular expansion in the number of festivals in France, explaining how numbers grew from about a dozen in the 1950s to more than a thousand in the mid 1990s. Meanwhile, Gibson and Connell (2005) suggest that there are over 600 music festivals in rural Australia alone.

A well established and substantial international literature now attests to the significant impacts generated by festivals across economic, political and socio-cultural domains (Arcodia and Whitford 2006). Growing awareness of these potential benefits, particularly in economic and tourism terms, has further propelled the proliferation already being driven by a series of demand and production-side factors. On the demand side, socialisation needs, the growth of serious leisure (Prentice and Andersen 2003) and the move towards the consumption of experiences (Getz 2008) have been important. In terms of the latter, key drivers have been festivals' potential to deliver a series of development outcomes related to economic restructuring and revitalisation, destination repositioning, inward investment and tourism revenue generation. Largely for these reasons, public agencies, in various spatial spheres, have become increasingly active in supporting and sometimes organising arts festivals. Thus, arts festivals, as well as other types of events more generally, have become part of a wider 
range of 'cultural strategies' (Gotham 2005, Shin 2004) used to regenerate and orient post-production economies towards consumption (Zukin 1995) where leisure, entertainment and tourism underpin an 'experience economy' (Pine and Gilmore 1990).

\section{Arts festivals and cultural policy}

Cultural policy makers have long been cognisant of the value of festivals. The link between festivals, cultural identity and national identity (Matheson 2005), has been recognised for some time. In the post war era, the flourishing of arts festivals in Europe noted by Rolfe (1992), Allen and Shaw (2000) and Finkel (2009) was heavily supported by national states which recognised in festivals an opportunity to re-affirm 'appropriate' cultural values, encourage social stability and boost morale. Over time, festivals have been used by national bodies and also by powerful societal groups to further political aims. An example of the latter is the South African National Arts Festivals, established in the 1970s by the 1820 Settlers Foundation with the aim of preserving and building English cultures in the face of rising Afrikaner nationalism (Snowball and Willis 2006). More recently, Yardimci (2007: 3) related the Turkish press' reporting of the establishment of the International Istanbul Festival in Turkey by the Istanbul Foundation for Culture and Art, as 'our sweetest dream, the eagerly awaited Istanbul Festival, has been presented to the world, with its whole grandeur and as an ever-improving reality'.

Over time, the support afforded the 'high arts' in Europe in the immediate post-war period was extended to popular and community arts. Autissier (2009: 31) writes that between 1960 and 1980 festivals 'served more diverse purposes': attracting tourists, promoting contemporary work, engaging minority cultures and reaching out to different styles of music. Illustrating wider trends and reflecting international views on the role of culture in society, by the late 1980s, the Arts Council in Ireland espoused the view that 'festivals encourage participation in creative activity in people of all ages, from all levels of society, in both urban and rural areas' (Arts Council 1992); and that 'all people, wherever they might live, have the right to access to the arts and .... the right to cultural self-determination'(Cloake 1995: 15). Reflecting and informing broader societal dynamics and changing policy needs, cultural policy thinking about the role of festivals gradually broadened to assume social dimensions. 
The Scottish Arts Council (undated: 5), for example, became one of the many public agencies to argue that festivals serve the important social function of creating identity and helping to weld communities'. Landry et al. (1993: 50) defined the social impact of the arts as those 'effects that go beyond the artefacts and the enactment of the event or performance itself and have a continuing influence on, and directly touch, peoples' lives. Meanwhile, festivals continue to be supported for their identity enhancing roles. In the context of the Caribbean, for example, (Nurse 2004: 223) has pointed out how festivals contribute by 'perpetuating and transplanting Caribbean culture and values and thus influencing global culture, media and public opinion'. In France, in the 1990s, the cultural policy remit attached to festivals was three-fold: asserting territorial distinction or identity; attracting tourists and promoting access to culture (Autissier 2009).

Most fundamentally, however, cultural policy-makers and their agents have historically fostered arts festival development for a host of artistic reasons. As Richards (1976) argued, festivals serve as catalysts, creating interest and initiating activity in the arts. Arts festivals offer possibilities for crystallising, galvanizing and articulating local identities. Historically, they represented opportunities for local agents to act and influence their localised arenas. Until recently, in both urban and rural areas, the majority of arts festivals emerged as 'bottom-up' initiatives and developed organically, often crystallising around the energies of a small group of highly committed artists and arts enthusiasts. Even in Edinburgh, a city which 'has served as a model for many of the world's leading international festivals', most festivals developed in an 'organic rather than a top-down fashion' (Scottish Arts Council 2006: 4). Often, the preoccupation was to meet some artistic need felt by a place-based community or by a particular artistic community, and the coherency of the endeavour only became apparent when viewed within wider spatial and temporal artistic contexts. Molloy (1980: 26) wrote that 'the success of multi-media arts festivals inspires further arts activities during the rest of the year' and that festivals 'provided the right environment for the establishment of arts centres'. Even today, while some arts festivals achieve very high profile, international status, they are often deeply embedded in place, committed through a long-term framework to achieving a defined set of artistic, cultural and societal goals. In 2009, the Arts Council in Ireland continues to prize them because they 'are very visible, dynamic and effective 
instruments in the development of an arts infrastructure'. Thus while contemporary arts festivals may fulfil a plethora of diverse roles and deliver an array of beneficial outcomes, when stripped bare, as De Greef (2008) explains, arts festivals exist for artistic reasons. They 'stage exceptional pieces of art, present new art forms and supply new creative possibilities'. (Their essence lies in) 'making room for art and artists to reach the largest public' (De Greef 2008: 1). The Arts Council in Ireland concurs, relating their support of festivals to the latter's role in creating 'a context for artistic risk-taking' and for encouraging 'the development of new and different audiences' (www.artscouncil.ie. Accessed 25/09/09). Implicit here is the notion that they form an integral part of their artform's wider world. Hence, some public arts agencies, like the Arts Council of England, for example, do not have a dedicated festivals policy. Rather, festivals are considered within the context of the relevant artform.

It is appropriate that the focus of this paper is on urban areas, as arts festivals have long been associated with cities. The contemporary period is no exception as amidst the general proliferation of festivals, urban arts festivals are becoming increasingly visible (Pejovic 2009). Amidst large, concentrated populations, festivals' power to attract, educate and reach out to the largest public is optimal. In addition, festivals have often experimented with city spaces, both in the public and private realm, to overtly challenge societal understandings about what constitutes 'appropriate' and acceptable cultural spaces and in the process, to act as a powerful advocate of change. Thus, if historically, early European high arts festivals reaffirmed the civilising and worthy high culture ideals through their association with the institutionalised urban landscapes of art galleries, concert halls and opera houses, in more recent times, alternative ideals have been physical expressed and tangibly reinforced in the use of unconventional spaces (e.g. public streets, disused warehouses, vacant retail spaces) for artistic performances.

\section{Arts festivals and urban tourism}

If festivals have proliferated in urban areas, an important driver has been the rise of urban tourism. From a tourism perspective, arts festivals represent a series of attractions appealing to external visitors and investors alike. Highly visible, energetic and attractive cultural activities, arts festivals are instantly appealing to tourism 
policy-makers seeking to animate and renew static attractions and destinations. Equally, for city governors, arts festivals are good for appearances, and it is frequently argued that attractive appearances are required in order to attract not only tourists, but also inward investors and creative workers. Hoffman, Fainstein \& Judd (2003) concur. When writing about how urban destinations are on the rise they argue that culture is the source of urban attraction. There is now abundant evidence showing that countless festivals are marketed as tourist attractions and generate sizeable flows of tourist numbers and revenue (Getz 1991, O'Sullivan and Jackson 2002). As De Greef (2008: 1) explains: 'festivals receive more attention in the media and reach larger audiences .... this is why many - regional, urban or national - governments will support and even organise festivals. Festivals are functioning remarkably well within the attraction programmes of governments'. In recent years 'festival tourism' has entered the tourism lexicon (O'Sullivan and Jackson 2002, Robinson et al. 2004), as festivals come to be viewed as a particular form of cultural tourism (McCarthy et al. 2007).

In one sense, there is nothing particularly new about the place-marketing role played by festivals. Gold and Gold (2005: 268), for example, described how the recognition of Greenwich as the fulcrum of the earth's time zones in 1884 inspired the hosting of a year-long festival intended to boost international tourism to London. While from the outset, this paper has construed arts festivals as being naturally at home in the cultural policy domain, other policy-makers have been cognisant of their value for some time. In Ireland, festivals have been officially supported on occasion as a means of generating international tourism demand since at least the 1950s. The Dublin Theatre Festival was founded in 1957, for instance, with state grant aid designed to support events occurring during the shoulder months of the tourist season (http://www.dublintheatrefestival.com/aboutus/History.asp). Prior to the 1950s, a cultural organisation in Ireland could only be supported through one state agency / government department. That stipulation was altered by the Prime Minister of the day in the early 1950s to enable the fledgling Wexford Festival Opera secure subvention from both the Arts Council and Bord Fáilte, the state tourism agency. However, the fervour with which public agencies now invest in arts events to celebrate historical milestones and subvent festivals through tourism funding channels is unprecedented. It is one part of what Eisinger (2000), in noting the tendency for public agencies to 
invest in cultural and entertainment amenities, has described as a universal undertaking.

As already discussed, arts festivals are particularly synonymous with cities, and cities, in turn, are particularly synonymous with tourism. According to Timur and Getz (2009: 221), favourable market conditions tempt many city planners to make tourism development an important part of urban policy, not only because tourism is a major economic activity but because it also promotes social development. Numerous cities have, in consequence invested tremendous resources and energy in either capitalising on well established festival resources or establishing and re-inventing new ones with tourism objectives in mind. Edinburgh immediately comes to mind as a city widely and popularly identified as a 'festival city'. However several other cities e.g. Singapore, Hong Kong and Manchester have used festivals to further a range of strategic goals. This is well acknowledged in the urban studies literature with several commentators noting how arts festivals are part and parcel of the cultural entrepreneurial strategies employed to reposition and re-brand cities (Kong 2000, Schuster 2001, Shin 2004).

From tourism development, destination branding and city positioning perspectives it would seem that 'arts festivals as product' is a very attractive proposition. Most of the non-academic research done on the topic has taken the form of economic impact studies, and usually, these results are positive, a fact at least partially due to the reality of public agencies' needs to justify investment in festival strategies. The academic literature on planned events, (of which arts festivals are one example), has tended to be absorbed with economic impacts and while there has been considerable debate as to the accuracy and robustness of the methodologies employed (Lee and Taylor 2005), beneficial outcomes have been posited. Beyond that, researchers have frequently argued that festivals are important in terms of social capital, in that they constitute sites for communal engagement, for expressions of communal solidarity and identity, and for opportunities to socialise with friends and family. In these contexts, (Maughan 2009: 59) argues that high on the list of what draws people is personal transformation, thus supporting Waitt's (2008: 520) assertion that urban festivals theoretically offer the possibility of 'forging a stronger place-based sense of 
belonging which can help diminish an anxiety cultivated by real fears of the loss of both home and livelihood'.

\section{Proliferating or flourishing ?}

Thus, it seems clear that arts festivals definitely deliver benefits for cities in a variety of ways. However, the question remains as to how arts festivals prosper under prevailing and powerful neo-liberal urban agendas, of which urban tourism policies form part. While arts festivals are proliferating, it remains unclear as to whether they are also flourishing. A number of problems have been articulated and often, debates on the 'festivalisation' of cities have been negative. Harvey (1989: 102) was one of the earliest to express concern that cultural entrepreneurialism would result in cities where cultural substance becomes replaced by cultural spectacle. Urban festivals as sites of spectacle become for city managers a highly prized, marketable economic resource (Waitt 2005) used to generate what Zukin (1995) refers to as cultural capital, which in turn increases the attractiveness of cities for inward flows of mobile capital, visitors and workers. There has been growing criticism of increasing homogeneity and declining creativity within arts festival activity (Fainstein and Judd 1999, Richards and Wilson 2006, Finkel 2009), as festivals slavishly respond to the diverse demands of public agencies and tout for sponsorship in the increasingly crowded festival market-place. The drive to create spectacle in turn seems to limit rather than enhance creativity (Waitt 2005), to promote what Richards and Wilson (2006) have termed 'serial homogenisation' and to limit the potential of meaningful civic engagement with the making of festivals (Eisinger 2000). Arguments such as these are now well researched in the literature. In truth, however, there is a paucity of empirical research to support and illustrate the validity of these arguments in cultural contexts (Richards 2007), and specifically in arts festival contexts. Finkel's (2009) recent study of combined arts festivals in the UK is useful in this regard. Her data are helpful in addressing the question of programming diversity and distinctiveness. Given the scale of competition, one might expect a diversity of programming across festival populations in the attempt to assert difference and stand out in a crowded marketplace. Her data suggest that despite there being more combined arts festivals in the UK than ever before, most of the ones that she researched are near "carbon copies" of each other. She found little difference between programme content irrespective of the 
age of the festival and attributes this to the 'uncreative responses of many organizers' to increased competition and funding bodies' shifting priorities.

More generally, critiques are rooted in the extent to which cultural strategies fail to connect with the specificities of the places within which they are located. Writing about the rise of 'flagship' projects (e.g. museums, galleries, mega-events) in urban strategies, Jones (2000, cited in Smith 2005) suggests that a number of projects have failed not only for financial reasons, but also because they are largely inappropriate for the local community and cultural infrastructure. He contrasts the success of the Millenium rugby Stadium in Cardiff with the lesser popularity of the city's Centre for Visual Arts, arguing that this directly reflects the differential in the city populace's interest in both modern art and rugby. Elsewhere, Smith (2005: 26) suggests that while many cities might wish for an internationally renowned iconic flagship, it is the uniqueness of the structure, its location and cultural context that partly shapes its success'. She supports her argument by suggesting that the failure of Sheffield's National Centre for Popular Music was perhaps due to its lack of a distinctively strong musical heritage.

Continuing this theme in the context of festivals (and events), Gotham (2005) argues that once encompassed as part of a city's tourism supply, they can be promoted by powerful economic forces in ways that undermine local traditions and decisionmaking. This is a central tenet in Eisinger's (2000) thesis that the preoccupation with meeting visitor needs can lead to events disregarding local residents. The implicit notion of displacement here is taken up by Misener and Mason (2006: 385) who, writing about sports events, examine how events transiently reproduce space in ways that disrupt or at least alter, local ways of living in place. They suggest that local citizens 'often struggle to find meaning, a sense of identity and a sense of connectedness in their own neighbourhoods' as one-off events transform the space around them.

A noticeable feature of these recent developments is that it is now not unusual for city planning documents and tourism strategies to refer to arts festival activity without any real reference to the underpinning artform, or to the identification or measurement of anticipated artistic outcomes. As Klaic (2009: 213) writes, 'the ongoing explosion of 
artistic festivals of all sorts makes one doubt whether the term still has any validity, since it is being applied in an arbitrary fashion to a tremendous number of divergent phenomena, driven by various artistic, political, community and commercial purposes'. He goes on to tentatively conclude that fundraising and marketing considerations are becoming more important, with potential artistic objectives being marginalised in the process (Klaic 2009: 223), although his final assertion is that festivals continue to generate a series of positive artistic outcomes. Other commentators, however, unequivocally argue that the spectacular aspects of festivity and the flows of visitors, income, images and goodwill that it generates are what really matters. Getz (2009) asserts that public policy with respect to festivals most often relates explicitly to tourism, place marketing and economic development, with cultural considerations coming later. Saleh (2009), in an article critiquing the support offered to culture by both public and private sectors across the Arab world, asserts that culture is supported to enhance prestige or promote tourism, with funding decisions, for example, favouring big festivals over actual artistic production. Grodach and Loukaitou-Sideris' (2009: 364) reporting of a newspaper article announcing that in Los Angeles, the Department of Cultural Affairs was resurrected only after redefining its focus towards the promotion of cultural tourism in the city, further supports this case.

With increasing attention from a breadth of policy-makers, and the growing involvement of a variety of stakeholders, it could be argued that arts festivals are becoming more vital, more central to public policy agendas. Yet, it is striking to note an apparent contradiction whereby: while public agencies are increasingly engaging with arts festivals (Wood 2005, Grodach \& Loukaitou-Sideris 2009, Autissier 2009), the need to argue the case for public support of the arts more generally is as urgent as ever (Long et al 2009). Ireland's capital city, Dublin, where arts festivals have proliferated in recent times, is a case in point. For example, over the course of seven days in September 2009, the city witnessed the $52^{\text {nd }}$ opening of its now 17 day long Dublin Theatre Festival, the oldest specialist theatre festival in Europe. Just four days previously, it had seen the 15 day long 2009 Fringe Theatre Festival draw to a close. It also saw the $250^{\text {th }}$ anniversary of the signing of the lease on the Dublin-based, now world famous Guinness Brewery, an occasion being marked, and marketed, with a series of cultural events and festivities across three continents. Finally, the city hosted 
its $4^{\text {th }}$ Culture Night, when 120 diverse cultural organisations opened their doors and spaces into the evening to an estimated one million people for free. The signs, sights and sounds of these cultural events enlivened the city's streets with billboard ads, posters and banners, and animated them with taster performances and street acts. They encouraged residents to explore little frequented parts of the city-centre, drew shoulder-season visitors into the city and generated heightened activity across city districts in a host of sectors including transport, hospitality and accommodation. Certainly, the cultural offerings of these events, as well as the colourful media coverage and commentary representing Dublin as a city en fête, bolstered public mood and helped to distract people from the surfeit of recessionary woes that the country currently finds itself faced with.

Yet, despite the celebratory, cultural festivity depicted above, cultural policy-makers are peripheral in the national political arena and the cultural sector in Ireland is currently preparing itself for potentially serious cutbacks in the Government's forthcoming budget. The national agency for funding, developing and promoting the arts in Ireland is facing the prospect of reduced state funding to the arts sector, while the future existence of both the Irish Film Board and Culture Ireland, the state agency which promotes Irish culture abroad, is under threat (Godley 2009). Indeed, while all those cultural happenings listed above were enlivening the city, internationally renowned Irish artists were busy countering the prospect of arts cutbacks with the launch of a 'National Campaign for the Arts' (http://nationalcampaignforthearts) (Falvey 2009).

The apparent contradiction evident here is not unique to Dublin. Rather, it is argued that the ironies and contradictions apparent in these cultural happenings have a relevance that goes to the core of the often problematic complexities characterising arts festival, urban tourism and cultural policy relationships. While the proliferation of arts festivals signals expansion and development for the sector, the ready transferability of arts festivals into tourist attractions and city image-makers raises the prospect of a new dichotomy within a city's supply of artistic offerings, with the visible and instantly appealing, e.g. festivals, being more likely to prosper through a variety of public funding, public-private ventures and private sponsorship arrangements, than those cultural organisations with less potential for spectacle. In the 
aftermath of Cork city's designation as European City of Culture, for example, the municipal authority introduced 5 'legacy' grants for city-based arts organisations. Four of the five grants were given to support the hosting of events (Quinn 2010). In such cases, city authorities can readily point to evidence of their ongoing support of cultural activity as well as to the vibrancy of the festival scene, yet these are indicators that could mask difficulties facing arts activities more generally. By way of explanation, it would seem that arts festivals and arts events have become somewhat disconnected from their original policy domain, with their current high profile due not so much to their artistic merit per say, but rather to the relevance they hold for other policy agendas like tourism and city re-imaging.

At core, the problem being argued here is a policy one. Set within a broad array of neo-liberal, culture-led urban regeneration strategies, arts festivals are now a mainstay of urban tourism policy-making. Most obviously manifest in their reproduction as tourist attractions, it seems clear that current conceptualisations of arts festivals within urban policy and urban tourism frameworks are imbalanced. Questions exist as to the sustainability of this scenario for the long term artistic vibrancy and creativity of arts festivals activity itself; and by extension, for the future vitality of the wider arts sector.

\section{Towards more balanced policy approaches}

There is a need for further research to find answers to these questions. More empirical investigation is needed to guide future policy development. In theory, it should be possible to approach policy making for arts festivals from a variety of perspectives simultaneously and to produce appropriate yet diverse outcomes for different stakeholder groups. This assertion is supported by the literature on festivals and authenticity which argues that different sets of valid meanings can be produced simultaneously for a variety of producers and consumers (Müller and Pettersson 2005, Richards 2007). However, in light of the research evidence reviewed above, the literature reveals few cities to be actively seeking to find a balanced approach. Perhaps Edinburgh is one. Festivals Edinburgh, the city's official festivals organisation now comprises eleven annual festivals, some dating back more than 60 years. The city is well cognisant of the economic and cultural role played by festivals in city life and impact studies on the festivals date to at least 1990 when the then 
Scottish Tourist Board produced an economic impact study. Strategic thinking about festivals is well established with a festivals strategy in place since 2001, an events strategy in place since 2002, both testimony to the city's commitment to supporting festivals in the city (Ali-Knight and Robertson 2004). More recently, the Scottish Arts Council (2006) published Thundering Hooves, a report intent on maintaining the global competitive edge of Edinburgh's festivals. As the background to the report explains, the partnership of agencies behind the report were concerned about the potentially long term decline in Edinburgh's status as a cultural city in the eyes of artists, promoters, audiences and media. The breadth of the partnership behind the report (arts, city, business and events) and the long-term and diverse nature of the recommendations interweaving cultural, economic and other domains like training and research suggests a balanced approach to strategising about festivals.

In this respect, there are close parallels evident in the links between sport and tourism; and arts festivals, the arts, culture and tourism. Higham (2005) suggests that strategic planning for sport tourism lies beyond the capacities and resources of just one of the parent disciplines, yet according to Devine et al (2009) evidence of international collaboration between public agencies in the development of sports tourism is limited. The latter briefly review a number of publications that point to the lack of communication and collaboration between sports and tourism agencies in countries including England, South Africa, the USA and Malta, before reporting the results of research into inter-organisational relationships in sports tourism policy domains in both the Republic of Ireland and in Northern Ireland.

The ongoing development of knowledge in the sports tourism arena has as yet no parallel in the arts tourism, or indeed, in the festival tourism arena. This is a key area in need of urgent redress if for no reason other the fact that as evidenced in the literature reviewed throughout this paper, policy-making and planning for arts festivals is continuing apace, but in often highly unbalanced ways.

A case in point is that of Ireland, where the arts sector is heavily reliant on state funding. Efforts to develop synergies between the culture and tourism sectors at national level in Ireland have become more apparent in recent years. A 2003 reconfiguration of government departments placed both the arts (although not 
heritage) and tourism under the auspices of one government department, that of Arts, Sports and Tourism. Two years, later a task force was formed to examine potential synergies between the arts and tourism and in 2006 a report 'Securing the Potential of Cultural Tourism for Ireland' was produced. Most recently, the Department's Departmental Business Plan 01/01/08 - 31/12/08 talks strategically of the need to 'work with relevant agencies to identify and agree ... linkages between tourism, arts, culture, film, music and the creative sectors, and seek to optimise synergies'. In addition, recent Ministers for Arts, Sports and Tourism have variously commented on the links between tourism and the arts, noting the mutual benefits of closer engagement and sometimes advocating changes and or developments to ally the two more closely.

The institutional arrangements for both the arts and tourism in Ireland involve a governmental department controlling state budgets and formulating national policies, aided by the existence of state agencies, operating on the 'arms length' principle to implement development supports for the sectors. In recent years, the state's national tourism development agency, Fáilte Ireland, has become markedly active in the cultural tourism area. In 2002, it began strategically investing directly in the sector through its Festivals and Cultural Events Initiative and in 2007, it published a new national strategy document: 'Cultural Tourism: Making it Work for you'. In contrast to the enthusiasm displayed by Fáilte Ireland, the state agency for the development of the arts, the Arts Council, has remained relatively silent on the issue. Planning and strategising about linking the arts, including festivals, with tourism, has been driven largely by the energies of the tourism agency .

This lack of engagement on the part of the arts sector in Ireland is perhaps not surprising, but it merits investigation and certainly needs redressing. At a two day academic-practitioner workshop on the topic of arts-tourism partnerships, held in October 2007 (Quinn \& Kennelly 2008), the Director of the Arts Council addressed the terms of engagement between the arts and tourism sectors. She expressed the Arts Council's preparedness to take an active role in leading cultural tourism development, while making it clear that the issue at hand was not simply one of 'making hay' with Ireland's international cultural reputation. Further, she explained that an advancement of the process would depend upon appropriate networking and that a useful basis for 
cooperation lay in the two sectors' mutual need to connect with audiences. From an arts perspective, she argued that an ultimate core aim is to make it easier for the visitor to access information about what's going on in the arts world. Issues identified as obstacles to potential cooperation in the Irish context included the fact that the planning cycle in the arts is much shorter than in tourism; that the arts sector finds the working structures of the tourism sector difficult to engage with; and that a general need exists for the two sectors to become more comfortable with the prospect of working with each other.

Cross-sectoral engagement is only beginning in Ireland. One undisputed common basis for cross-sectoral collaboration is audience development. Tourism represents opportunities for expanding and developing audiences, yet it is usually tourism agents as opposed to festival organisations themselves, who are most proactive and alert to exploiting these opportunities. The Galway Arts Festival, one of the largest and most internationalised arts festivals in Ireland is a case in point. On its manager's own admission, this festival 'stumbled' into tourism. It realised that 'people were out there trying to find information about the Festival and they were not doing anything about it' (Quinn \& Kennelly 2008: 6). Efforts to collaborate with regional and national tourism agencies have since begun to redress this matter. Elsewhere, there are the very earliest signs that obstacles to collaborative policy-making are being identified and solutions sought. For example, the mis-match between the short-term planning cycles of the arts world (determined as they are by a general absence of long-term, secure income) and the longer-term planning needs of tourism has been partially addressed with the introduction of multi-annual funding for a small number of internationally ranked arts organisations (including festivals). The influence of tourism considerations in prompting this new development seems paramount.

\section{Concluding comments}

Based on the literature reviewed in this paper as well as the references made to the Irish situation, it seems clear that a need exists for common bases for collaboration to be identified between the arts festivals and tourism sectors, and for these common bases to be conceptualised within the broader urban policy arenas in which arts festival are now firmly implicated. Getz' (2009) thinking in identifying relevant policy areas and their associated goals, policy initiatives and performance measures 
establishes a logical starting point. For him, a key driver is the need to address sustainability concerns, and he argues the need for all relevant stakeholders to sit down and work out their goals, objectives and expected outcomes. As he admits, however, this is very ambitious. It can be relatively easy to identify potential synergies between two productive sectors like tourism and the arts, and while some form of arts tourism planning can proceed at the behest of just one of the sectors, this is unlikely to be equitable or sustainable in the long term. Yet, affecting the appropriate changes in collaborative policy-making and decision-making to enable synergies be translated into mutual benefits is not unproblematic. To tackle the complexities implicit in this task, further research is needed into the multi-faceted roles that contemporary arts festivals play in contributing to the artistic activities, cultural vibrancy and economic vitality of urban societies in general. In 2005 Miles and Paddison (2005: 834) asked 'do we really understand the complex nature of the alignment of the arts with other policy realms'? It would seem that in respect of arts festivals, the need to re-state this question is as real as ever. Urban arts festivals may be proliferating, but that does not necessarily mean that they are flourishing. Even if one could argue that artistic activity, as manifest in arts festival activities is prospering, this prosperity cannot be assumed to be reflected in arts activity more widely. This situation is hardly desirable and points to continued fracturings between arts festivals, urban tourism and cultural policy domains that need to be mended. 


\section{References}

Arcodia, C. and Whitford, M. (2006) Festival attendance and the development of social capital. Journal of Convention \& Event Tourism, 8(2), 1-18.

Ali-Knight, J. and Robertson, M. (2004) Introduction to arts, culture and leisure. In Yeoman, I.; Robertson, M.; Ali-Knight, J.; Drummond, S.; McMahon-Beattie, U. (eds) Festival and Events Management. An International Arts and Culture Perspective. Oxford, UK and Burlington, Massachusetts, USA: Elsevier ButterworthHeinemann. 3-13.

Allen, K. and Shaw, P. (2000) Festivals Mean Business. The Shape of Arts Festivals in the UK. British Arts Festivals Association Report.

Arts Council (1992) Art Matters. 13, p.4. Dublin: Arts Council.

Arts Council Festivals and Events. Summary Policy Paper. www.artscouncil.ie Accessed online 25/09/09.

Brennetot, A. (2004) Des festivals pour animer les territories, Annales de Géographie, $635,29-50$.

Autissier, A. M. (2009) Introduction. In A. M. Autissier (ed) The Europe of Festivals: From Zagreb to Edinburgh, interesting viewpoints ... Toulouse and Paris: edition de l'attribut and Culture Europe International. 21-4I.

Cloake, M. (1995) The regional development of the arts in Ireland: future structures and relationships. Paper presented to the Cork Arts Development Committee Conference, May 5-6, Cork Opera House, Cork.

Cultural Tourism Task Force (2006) Securing the Potential of Cultural Tourism in Ireland. Report presented to the Minister for Arts, Sports and Tourism and to the Chair of Fáilte Ireland. Dublin: Department of Arts, Sports and Tourism. 
De Greef, H. (2008) Introductory Speech. European Festivals Association Declaration on Intercultural Dialogue. www.efa-aef.eu. Accessed 08/09/09.

Department of Arts, Sports and Tourism (2008) Departmental Business Plan 01/01/08 -31/12/08. Dublin: Department of Arts, Sports and Tourism

Devine, A. Boyd, S. \& Boyle, E. (2009, June) Unravelling the complexities of interorganisational relationships within the sports tourism policy arena on the island of Ireland. Paper presented at the Tourism \& Hospitality Researchers in Ireland Conference (THRIC), Dublin Institute of Technology, Dublin.

Dublin Theatre Festival http://www.dublintheatrefestival.com/aboutus/History.asp. Accessed November 9th 2009.

Eisinger, P. (2000) The politics of bread and circuses: Building the city for the visitor class. Urban Affairs Review, 35 (3) 316-333.

Fáilte Ireland (2007) Cultural Tourism. Making it Work for you. Dublin: Fáilte Ireland.

Fainstein, S. and Judd, D. R. eds. (1999) The Tourist City. New Haven and London: Yale University Press.

Falvey, D. (2009) Wealth of talent supports campaign against arts cutbacks. Irish Times, 24/09/2009.

Finkel, R. (2009) A picture of the contemporary combined arts festival landscape.

Cultural Trends, 18 (1), 3-21.

Getz, D. (2009) Policy for sustainable and responsible festivals and events: institutionalization of a new paradigm. Journal of Policy Research in Tourism, Leisure and Events, 1 (1), 61-78.

Getz, D. (2008) Event tourism: definition, evolution and research. Tourism Management 29, 403-428. 
Getz, D. (1991) Festivals, Special Events and Tourism. New York: Van Nostrand Reinhold.

Gibson, C. and Connell, K. (2005) Music and Tourism. Clevedon: Channel View Press.

Godley, G. (2009) Five ways culture can save us. Irish Times. 23/09/2009.

Gold, J. R. and Gold, M. M. (2005) Cities of Culture: Staging international Festivals and the Urban Agenda, 1851 - 2000. Aldershot: Ashgate.

Gotham, K. F. (2005) Tourism from above and below: globalization, localization and New Orlean's Mardi Gras, International Journal of Urban and Regional Research, 29 (2), 309-26.

Griffiths, R. (2006) City/culture discourses: evidence from the competition to select the European Capital of Culture 2008 European Planning Studies 14 (4), 415 - 430.

Griffiths, R., Bassett, K. and Smith, I. (2003) Capitalising on Culture: Cities and the Changing Landscape of Cultural Policy. Policy \& Politics, 31(2), 153-169.

Grodach, C. \& Loukaitou-Sideris, A. (2009) Cultural development strategies and urban revitalization, International Journal of Cultural Policy, 13 (4), 349-370.

Harvey, D. (1989) From managerialism to entrepreneurialism: the transformation in urban governance in late capitalism, Geograpfiska Annaler, 71(B), 3-17.

Higham, J. (2005) Sport Tourism Destinations - Issues, Opportunities and Analysis. London: Butterworth-Heinemann.

Hoffman, L. K., Fainstein, S. S. \& Judd, D. R. (2003) (Ed.s) Cities and Visitors: Regulating People, Markets and City Space. New York: Blackwell Publishing. 
Isar, R. F. (1976) Culture and the arts festival of the twentieth century, Cultures, 3, $125-145$.

Klaic, D. (2009) From festivals to event planning. In A. M. Autissier (ed) The Europe of Festivals: From Zagreb to Edinburgh, interesting viewpoints ... Toulouse and Paris: edition de l'attribut and Culture Europe International. 213-223.

Kong, L. (2000) Cultural policy in Singapore: negotiating economic and sociocultural agendas. Geoforum, 31, 409-424

Landry, C. et al. (1993) The Social Impact of the Arts. Stroud, UK: Comedia.

Lee, C. K. and Taylor, T. (2005) Critical reflections on the economic impact assessment of a mega-event: the case of the 2002 FIFA World Cup. Tourism Management 26, 595-603.

Long, J. Jowell, T \& McMaster, B. (2009) Shaping cultural policy. Journal of Policy Research in Tourism, Leisure and Events, 1(1), 79-89.

MacCannell, D. (1992) Empty Meeting Grounds: The Tourist Papers. London: Routledge

Matheson, C. M. (2005) Festivity and sociability: a study of a celtic music festival. Tourism Culture \& Communication, 5, 149-163.

Maughan, C. (2009) The economic and social impact of cultural festivals in the East Midlands of England. In (ed) The Europe of Festivals: From Zagreb to Edinburgh, interesting viewpoints ... Toulouse and Paris: edition de l'attribut and Culture Europe International.51 - 60 .

McCarthy, B., Moscardo, G. Murphy, L. \& Pearce, P. (2007, September) M2B2:

Mining and chamber music: terra nova, exploring new territory in the development of music-tourism networks. Paper presented at the Advances in Tourism Marketing Conference, Valencia, Spain. 
Miles, S. and Paddison, R. (2005) Introduction: the rise and rise of culture-led urban regeneration. Urban Studies 42 (5/6), 833-840.

Misener, L. \& Mason, D. S. (2006) Developing local citizenship through sporting events: balancing community involvement and tourism development. Current Issues in Tourism, 9 (4/5), 384-398.

Molloy, D. (1980) About the Arts Council. Dublin: Arts Council of Ireland.

Müller, D. K. And Pettersson, R. (2005) What and where is the indigenous at an indigenous festival? Observations from the Winter festival in Jokkmokk, Sweden. In Indigenous Tourism: the Commodification and Management of Culture. Elsevier.

Nurse, K. (2004) Trinidad carnival: festival tourism and cultural industry, Event Management 8, 223-230.

O’Sullivan, D. and Jackson, N. J. (2002) Festival tourism: a contributor to sustainable local economic development? Journal of Sustainable tourism 10(4), 325-42.

Pejovic, K. (2009) Urban arts festivals: a mark on regions. In A. M. Autissier (ed) The Europe of Festivals: From Zagreb to Edinburgh, interesting viewpoints ... Toulouse and Paris: edition de l'attribut and Culture Europe International. 63 - 73.

Pine, B. J. \& Gilmore, J. H. (1999) The Experience Economy. Boston: Harvard University Press.

Prentice, R. and Anderson, V. (2003) Festivals as creative destination. Annals of Tourism Research 30, 7-30.

Quinn, B. (2010) (Accepted forthcoming) The European Capital of Culture initiative and cultural legacy: an analysis of the cultural sector in the aftermath of Cork 2005. Event Management 13(4). 
Quinn, B. and Kennelly, K. (2008) Building Best Practice through Partnership: Developing Arts Tourism in Ireland. Unpublished Paper. Dublin Institute of Technology.

Richards, G. (2007) Culture and authenticity in a traditional event: the views of producers, residents and visitors in Barcelona. Event Management, 11, 33-44.

Richards, G. and Wilson, J. (2006) Developing creativity in tourist experiences: a solution to the serial reproduction of culture, Tourism Management 27(6), 1209-1223.

Robinson, M., Long, P. and Picard, D. (2004) Festival tourism: producing, translating and consuming expressions of culture(s). Event Management 8(3), 187-90.

Rolfe, H. (1992) Arts Festivals in the UK. London: Policy Studies Institute.

Saleh, H. (2009) Arab world can use culture to counter conservatism. Financial Times October 9th. www.ft.com/cms/s/0/ Accessed 04/02/2010.

Schuster, J. M. (2001) Ephemera, temporary urbanism and imaging. In L. J. Vales \& S. B. Warner (eds) Imaging the City - Continuing Struggles and New Directions. New Brunswick: CUPR Books. 361-396.

Scottish Arts Council (2006) Thundering Hooves: Maintaining the Competitive Edge of Edinburgh's Festivals. Executive Summary. Edinburgh: Scottish Arts Council.

Scottish Arts Council (undated) Festivals, Paper 9: A Charter for the Arts in Scotland. Edinburgh: Scottish Arts Council.

Shin, H. (2004) Cultural festivals and regional identities in South Korea. Environment and Planning D: Society and Space, 22, 619-632.

Smith, M. (2005) Tourism, culture and regeneration: differentiation through creativity, in Tourism, Creativity and Development. ATLAS Reflections 2005 (Eds.) Swarbrooke, J. Smith, M. and L. Onderwater. ATLAS, Arnhem, Netherlands. 
Snowball, J. D. \& Willis, K. G. (2006) Building cultural capital: transforming the South African national arts festival. South African Journal of Economics, 74(1), 2033.

Timur, S. and Getz, D. (2009) Sustainable tourism development: how do destination stakeholders perceive sustainable urban tourism? Sustainable Development 17, 220232.

Waitt G. (2008) Urban festivals: geographies of hype, hopelessness and hope. Geography Compass, 2 (2), 513-537.

Waterman, S. (1998) Carnivals for elites? The cultural politics of arts festivals. Progress in Human Geography, 22(1), 55-74.

Wood, E. (2005) Measuring the economic and social impacts of local authority events. International Journal of Public Sector Management 18(1), 37-53.

Yardimci, S. (2007) Festivalising difference: privatisation of culture and symbolic exclusion in Istanbul, EUI Working Papers RSCAS 2007/35. Florence: EUI.

Zukin, S. (1995) The Cultures of Cities. Cambridge, MA: Blackwell Publishers. 